\title{
Genetic Variation of Dacrycarpus imbricatus in Bromo Tengger Semeru National Park (BTS-NP), East Java Based on trnL (UAA) Intron Region
}

\author{
Apriyono Rahadiantoro, Luchman Hakim*, Estri Laras Arumingtyas
}

\author{
Biology Department, Faculty of Mathematics and Natural Sciences, Brawijaya University, Malang
}

\begin{abstract}
The conservation of Jamuju Dacrycarpus imbricatus in Java Island has been considered important. One of the the limitation of such program is related to the viability data on the genetic diversity of species target. The aim of study was to determine genetic variation of D. imbricatus in Bromo Tengger Semeru National Park (BTS-NP), East Java based on trnL (UAA) intron region. DNA sample was collected from several D. imbricatus seedling population in BTS-NP in East Java. DNA was isolated and amplified using PCR. Genetic variation was estimated using trnL (UAA) intron sequences. This study confirm that D. imbricatus in BTN-SP has low genetic diversity. Based on the phylogenetic tree, $D$. imbricatus population from BTN-SP is closely related to D. imbricatus from Sabah-Malaysia and HainanChina with $100 \%$ similarity value. These data implies that population and habitat management of $D$. imbricatus in BTN-SP should be designed to enhance the population survival in the future.
\end{abstract}

Keywords:Jamuju conservation, Genetic variation, mountain tropical forest

\section{INTRODUCTION}

Jamuju Dacrycarpus imbricatus is one of the native and endemic plant trees species which grow in Indonesia including Java, Southwest and Central Celebes, and all Lesser Sunda Island (Bali-Timor). D. imbricatus is individual tree in the wild can grow up to $50 \mathrm{~m}$ in talland belongsto Podocarpaceae family (Gymnosperm). The species has ecological function in carbon storage, support soil microbial community, increase soil nutrition, and in soil and water conservation. The habitat of $D$. imbricatus confirm to the mountain tropical forest $[1,2,3]$. In Indonesia, however, the status of $D$. imbricatus could be vurnerable and endangered due to rapid deforestation and massive illegal logging. As far, there are no population assess-ments and evaluation has been done during the past decades.

Bromo Tengger Semeru National Park (BTSNP) is one of the biodiversity hot spot areas in Java Island. In such park, D. imbricatus grows wild with manynative plant trees in primary and secondary forest. The existence of $D$. imbricatus

\footnotetext{
${ }^{*}$ Corresponding author:

Luchman Hakim

Biology Department, Faculty of Mathematics and Natural

Sciences, Brawijaya University, Jl. Veteran, Malang,

Indonesia 65145

E-mail: luchman@ub.ac.id
}

and many plant trees species which has economical value, however, becomes target of illegal logging. The wood of $D$. imbricatus was reported has good quality for material contruction. Our previous survey confirms that recent distribution of D. imbricatus was limited to forest area surrounding Ngadas and Ranupani. These implies that conservation of $D$. imbricatus was important.

Recently, genetic aspect has been considered as one of the important aspect in plant conservation strategy. Fundamentally, plant genetic variation and population size contribute to the plant's fitness and life [4]. There are many techniques available to identify genetic diversity through sequences analysis. Currently, the uses of $t r n \mathrm{~L}$ intron has been introduced. The $t r n \mathrm{~L}$ intron is non-coding region of chloroplast DNA which can detect genetic variation in plant. The chloroplast $t r n \mathrm{~L}$ (UAA) intron has advantage that is easy to amplification in a large number of plants (highly success PCR) to amplification in a large number of plants. Size of trnL intron is small enough allows the production of a complete DNA sequences $[5,6]$. Sequence variations of the chloroplast trnL (UAA) intron were detected in Taxus wallichiana [7], Panicum virgatum [8], and Raphanus [9].

The information of genetic diversity of jamuju is one of the important aspects to define the conservation strategy. As far, there is no in- 
formation available. The aim of study was to determine genetic variation of $D$. imbricatus in BTS$\mathrm{NP}$, East Java based on $\operatorname{trn} \mathrm{L}$ (UAA) intron sequences.

\section{MATERIALS AND METHODS}

\section{Sites of study}

DNA sample was collected from several D.imbricatus seedling population in BTS-NP, East Java. The seedlings of $D$. Imbricatus appear after rainy season in June-July. In these periode, seedling grows and young leaf available to collect as a sources of DNA materials. Ecologically, BTS-NP area is humid mountain tropical forest. The national park cover an area about 50,276 ha and spread from 1,200 to $2,450 \mathrm{~m}$ asl. The biodiversity of mountain flora and fauna was considered high. Many plant species were endemic to the park. Our previous survey found D. imbricatus distribute at several point in secondary forest at Ngadas and Ranupani.

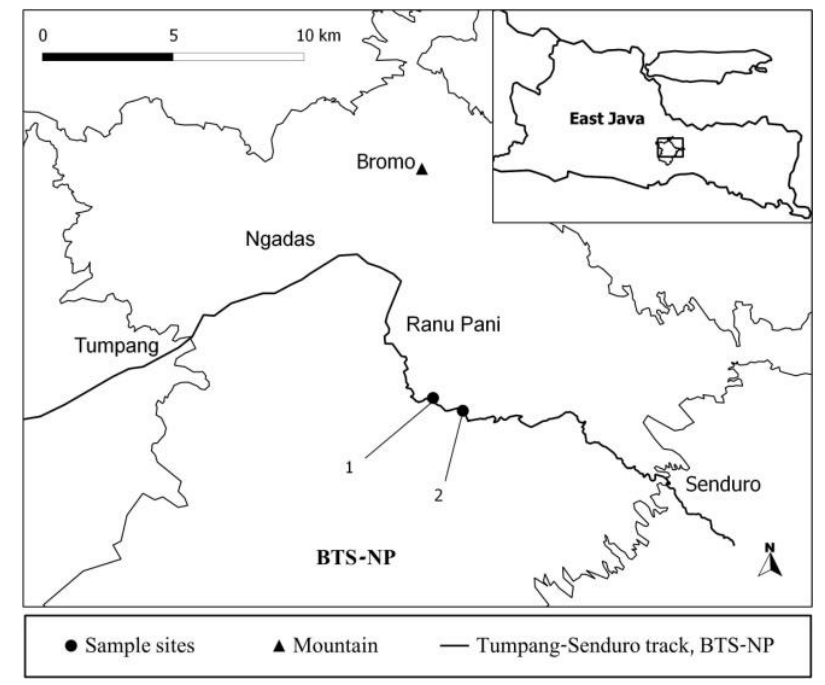

Figure 1. Map of Dacrycarpus imbricatus sample sites. BTS-NP: Bromo Tengger Semeru National Park

\section{DNA extraction}

Total genomic DNA was extracted from young leaf tissue of $D$. imbricatus seedling using the Doyle and Doyle CTAB method [10]. For the DNA purification DNA precipitation, the methods was modified by adding Phenol Chloroform-isoamyl alcohol and cold absolute ethanol. Quality of the extracted DNA was determined using gel electrophoresis and DNA concentrations were determined by measuring with a UV spectrophotometer. Isolated plant genomic DNA was preserved at $-20{ }^{\circ} \mathrm{C}$.

\section{PCR amplification}

Primer combinations trnL were:

c:(5'CGAAATCGGTAGACGCTACG-3')

d: (5'GGGGATAGAGGGACTTGAAC-3')

that were used for amplification of the trnL (UAA) region [5]. PCR was carried out in $30 \mu \mathrm{l}$ volume reaction mixture. The reaction mixture contained $6 \mu \mathrm{L} \mathrm{ddH}_{2} \mathrm{O}, 15 \mu \mathrm{L}$ PCR mix $2 \times$ solution (intRON biotechnology), $3 \mu \mathrm{L}$ DNA (100$350 \mathrm{ng} / \mu \mathrm{L}), 3 \mu \mathrm{L}$ primer $\mathrm{c}$ and $3 \mu \mathrm{L}$ primer $\mathrm{d}$ $(30 \mathrm{pmol} / \mu \mathrm{L})$. The trnL (UAA) intron thermocycling profile was: $95^{\circ} \mathrm{C}$ for 5 minutes, 35 cycles of $95{ }^{\circ} \mathrm{C}$ for 45 second, $61.7{ }^{\circ} \mathrm{C}$ for 45 second, and $72{ }^{\circ} \mathrm{C}$ for 45 second, with a final extension of $72{ }^{\circ} \mathrm{C}$ for 10 minutes. The PCR products were visualized on $1.5 \%$ agarose gel stained with ethidium bromide, sequenced using $3730 \times 1$ automated sequencer (Applied Biosystems, Macrogen Inc., Seoul, South Korea) and evaluated using ABI sequence Scanner v.10 (Applied Biosystems).

\section{trnL intron analysis}

Genetic variation was estimated using trnL (UAA) intron sequences from GenBank (Table 1). Sequences were aligned using Bioedit 7.0.9.0 and genetic distances were computed using MEGA 5.03. with Kimura-2-Parameter (K2P) evolution model [11]. The phylogenetic tree was inferred using Neighbor Joining (NJ), Maximum Likelihood (ML), and Maximum Parsimony (MP) method. Boot-strapping was performed with 1000 replicates.

\section{RESULTS AND DISCUSSION}

Evaluating genetic diversity is crucial in plant conservation strategy. This research confirms that seedling population of D. imbricatus in BTSNP has no genetic variation. It is shown by low level of polymorphism which was detected in the cpDNA trn L (UAA) region (Figure 2). The alignment of $\operatorname{trn} \mathrm{L}$ (UAA) intron shows the absence of deletions or insertions of nucleotides among the 10 samples. The $\operatorname{trn} \mathrm{L}$ (UAA) intron sequences from Gen Bank detect only two variable sites were found, one insertion and one transversion. The bases in position 350 show insertion of adenine (A) and the bases in position 452 show transversion of timine $(\mathrm{T})$ to guanine $(\mathrm{G})$. Transversion are changes from purine bases (A or $G$ ) to pyrimidine bases $(\mathrm{C}$ or $\mathrm{T}$ ) or pyrimidine bases to purine bases [12]. The result showed that the $\operatorname{trn} \mathrm{L}$ intron region was highly conserved. 
Table 1. Accessions of different taxa for $\operatorname{trn} \mathrm{L}$ intron sequence variation

\begin{tabular}{lllll}
\hline & \multicolumn{1}{c}{ Taxon } & \multicolumn{1}{c}{ Distribution } & Collector & GenBank accession number \\
\hline Outgroup taxa: & Podocarpus neriifolius & Nepal-New Zealand & Zhou, et al. & AY013736.1 \\
Ingroup taxa: & $\begin{array}{l}\text { Dacrycarpus } \\
\text { kinabaluensis }\end{array}$ & Sabah, Malaysia & Biffin, et al. & JN001415.1 \\
& Dacrycarpus cinctus & Sulawesi-New Guinea & Biffin, et al. & JN001413.1 \\
& Dacrycarpus imbricatus 1 & Sabah, Malaysia & Sinclair, et al. & AY083140.1 \\
& Dacrycarpus imbricatus 2 & Hainan, Cina & Zhou, et al. & AY013727.1 \\
\hline
\end{tabular}
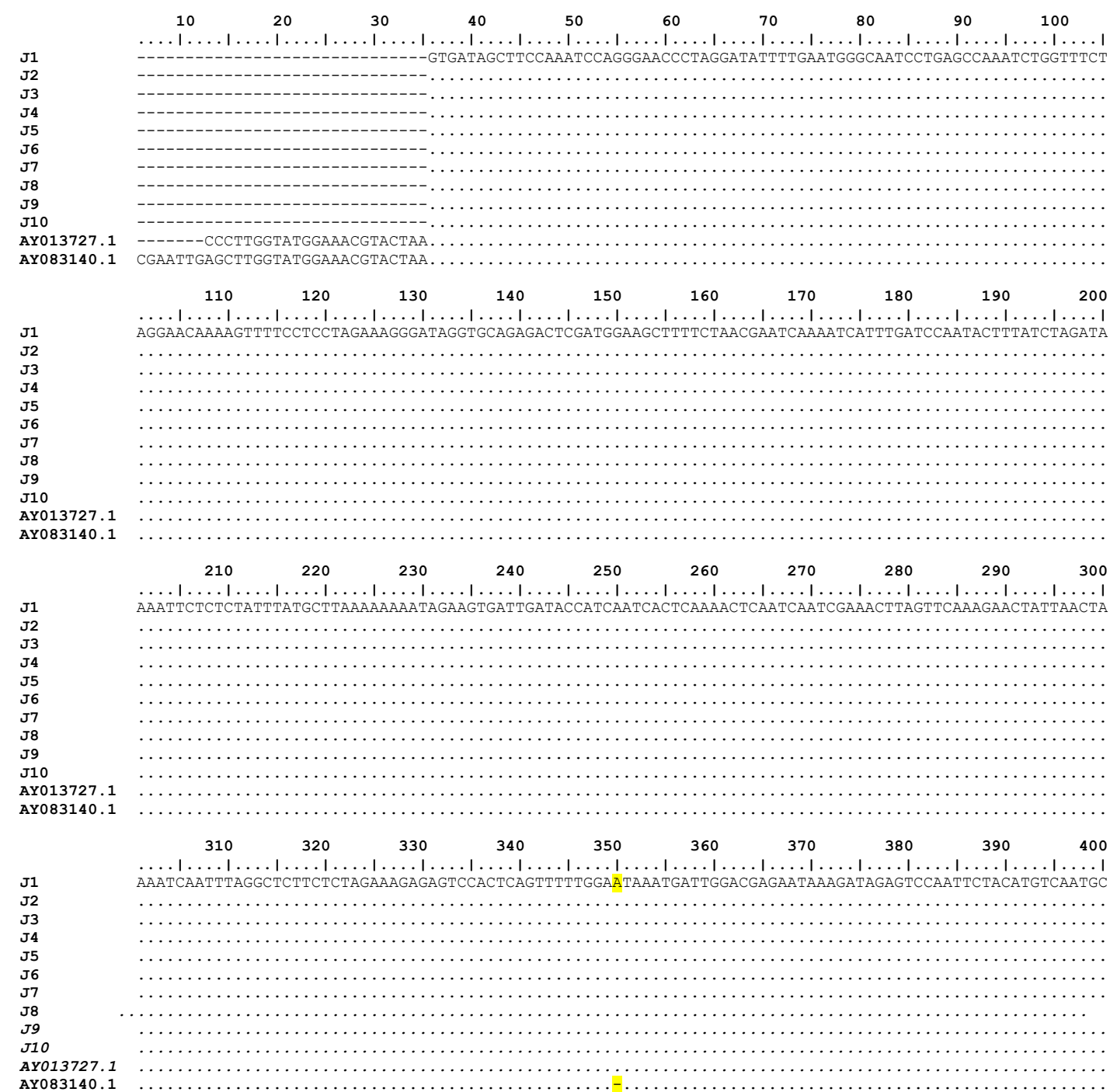

..

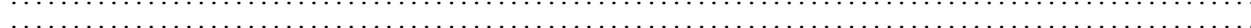



..

(1)

013727.1

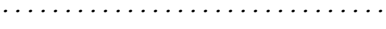

AY083140.1

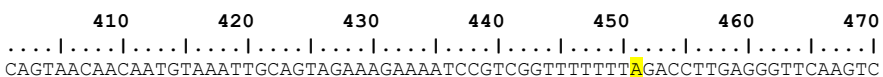

J1
J2
J3
J4
J5
J6
J7
J8
J9
J10
AY013727.1
AY083140.1

CAGTAACAACAATGTAAATTGCAGTAGAAAGAAAATCCGTCGGTTTTTTTAGACCTTGAGGGTTCAAGTC

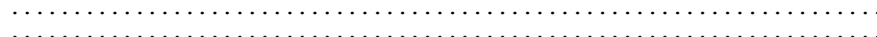

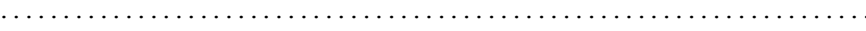

(2.

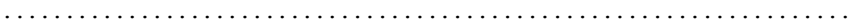

(n.

…

Figure 2. Alignment of the trnL intron of D. imbricatus. J1-10: Sampled population from BTS-NP. AY013727.1: The GenBank sequence accession number from Hainan-China. AY083140.1: The GenBank sequence accession number from SabahMalaysia. Dot (.) indicates that the character states are the same. Dash (-) indicates alignment gap 


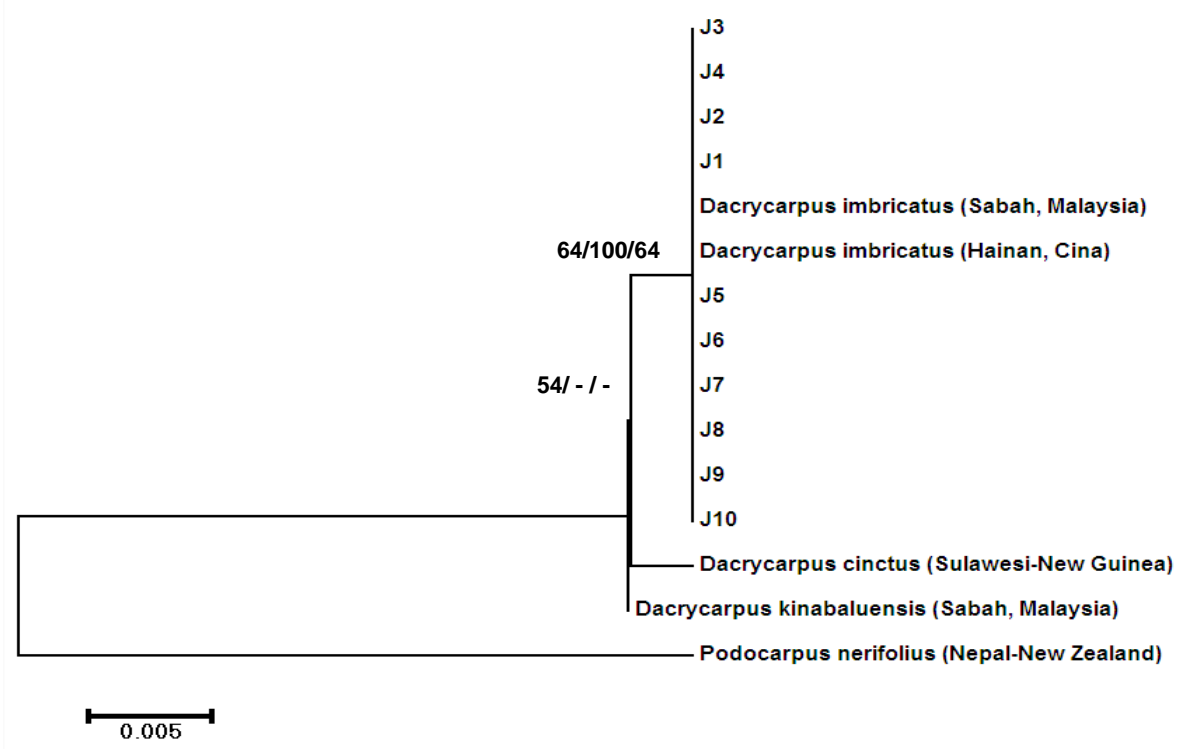

Figure 3. Phylogenetic tree of the jamuju based on trnL (UAA) intron sequences. J1-10: Sampled population from BTS-NP. Bootstrap percentages $(\mathrm{NJ} / \mathrm{MP} / \mathrm{ML}$ ) with a frequency of more $50 \%$ are shown in the nodes of the dendrogram

The aligned sequence lengths of the $\operatorname{trn} \mathrm{L}$ (UAA) intron regions were $470 \mathrm{bp}$. Compared to the sequences available in GenBank and also sequence produced in this research, the trn $\mathrm{L}$ (UAA)intron among ten samples of $D$. imbricatus were identical in length. Moreover they have a very high sequence identity (identities value $99 \%$ for $D$. imbricatus). The phylogenetic tree based on trn $\mathrm{L}$ intron show that jamuju from BTS-NP is closely related to $D$. imbricatus from SabahMalaysia and Hainan-China with $100 \%$ similarity value (Figure 3). In the context of phytogeography, these species seems similar and these species has low genetic diversity. Recent plant conservation strategy has been considerd phylogenetic as a key for conservation success [13].

In this study, the phylogenetic tree showed that the $D$. imbricatus clade is closely related to $D$. cinctus (origin: Sulawesi-New Guinea) with 99.5 $\%$ similarity value and $54 \%$ Neighbor-NJ bootstrap value (Figure 3). The phylogenetic tree showed D. imbricatus clade, well supported with bootstrap value (100\% in MP), $64 \%$ in NJ and ML. The high genetic similarities among the spesies show the presence of some associations in the evolutionary processes in Dacrycarpus and Podocarpus (Figure 3). The relationship between Dacrycarpus and Podocarpus has evaluated by the low rates of nucleotide substitution within sequences, suggesting that $\operatorname{trn} \mathrm{L}$ (UAA) intron suitable for phylogenetic studies [14].

Overall, the phylogenetic tree of the jamuju based on $\operatorname{trn} \mathrm{L}$ intron (Figure 3) support a statement that ancestor of Dacrycarpus is from south region (Antartica) [2]. According to fossil evidence and plant distribution, it is possible because
Cretaceous period (last dinosaur era), New Guinea still join with Antarctic plate, then in the mid-Tertiary period (early ice age), continent of New Guinea move away from Antartica plate and began to move closer to continent of Asia (East Java, Malaysia and Cina).

\section{CONCLUSION}

Sequence analysis revealed that the genetic variation within the seedling of D.imbricatus from BTS-NP was low. Considering the low individual number and recent population were distributed pactcy, the conservation of $D$. imbricatus becomes important. The habitat protection and plants regeneration are important approach, while in the same time establishing restoring wild seedling population is important. The trnL (UAA) intron was unable to detect genetic variation of jamuju in population level, it is useful for phylogenetic studies of Podocarpaceae.

\section{ACKNOWLEDGEMENTS}

This research was support and facilited by Japan International Cooperation Agency (JICA) and BTS-NP throught the project entitled Project on Capacity Building for Restoration of Ecosystems in Conservation Areas which is granted to Dr. Luchman Hakim.

\section{REFERENCES}

1. Whitten T, Soeriaatmadja RE, Afiff SA(1999) Ekologi Jawa dan Bali. Prenhallindo.Jakarta.

2. de Laubenfels (1988) Coniferales. In: Van Steenis CJGG eds. Flora Malesiana Series: 
Spermatophyta Flowering Plants 10 Part 3 Revisions. Noordhoff-Kolff NV. Jakarta.

3. Turner BL, Cernusak LA (2011) Ecology of the Podocarpaceae in Tropical Forests. Smithsonian Instution Scholaely Press. Washington DC.

4. Leimu R, Mutikainen P, Koricheva J, Fischer M. (2006) How general are positive relationships between plant population size, fitness and genetic variation?. Journal of Ecology94: 942-952.

5. Taberlet P, Coissac E, Gielly L, Miquel C, Brochmann C, Valentini A, Vermat T, Willerslev E (2007) Power and limitations of the chloroplast trnL (UAA) intron for plant DNA barcoding. Nat Hist 35: 1-8.

6. Gielly L, Taberlet P (1994) The use of chloroplast DNA to resolve plant phylogenies: Noncoding versus rbcL sequences. Mol. Biol. Evol 11: 769-777.

7. Gao LM, Moller M, Zhang XM, Hollingsworth ML, Liu J, Mill RR, Gibby M, Li DZ (2007) High variation and strong phylogeographic pattern among cpDNA haplotypes in Taxus wallichiana (Taxaceae) in China and North Vietnam. Mol Ecol; 1-15.

8. Missaoui AM, Paterson AH, Bouton JH (2006) Molecular markers for the classification of Switchgrass (Panicum virgatum L.) germplasm and to assess genetic diversity in three synthetic Switchgrass populations. Genet Resour Crop Ev. 53:1291-1302.

9. Yamagishi H, Terachi T, Ozaki A, Ishibashi A. (2009) Inter and intraspecific sequence variations of the chloroplast genome in wild and cultivated Raphanus. Plant Breeding 128: 172-177.

10. Doyle JJ, Doyle JL (1990) A rapid total DNA preparation procedure for fresh plant tissue. Focus 12: 13-15.

11. Sun Z, Gao T, Yao H, Shi L, Zhu Y, Chen S. (2011) Identification of Lonicera japonica and its related species using the DNA barcoding method. Planta Med. 77: 301-306.

12. Kass E, Wink M (1995) Molecular Phylogeny of the Papilionoideae (Family Leguminosae) RbcL Gene sequences versus chemical taxonomy. Bot. Acta 108: 149-162.

13. Winter M, Devictor V, Schweiger O (2012) Phylogenetic diversity and nature conservation: where are we?. TREE 1-6.

14. Kim AK, Ellis DJ, Sandler HA, Hart P, Darga JE, Keeney D, Bewick TA (2004) Genetic diversity of Dodder (Cuscuta spp.) collected from commercials cranberry production as revealed in the $\operatorname{trn} \mathrm{L}$ (UAA) intron. Plant Molecular Biology 22: $217-223$. 